"Yes-I see more hope, both for ourselves as doctors and for the people who will come under our care, in the future of medicine than perhaps in any other single thing in the new world towards which we are hacking our way. We at least have not-yet-forfeited the trust of people for whom we work ; we at least have not-yet-turned inwards in despair, bartering our spirit of adventure for a mere hope of security. We stand for sane knowledge, selflessness, and mercy in a world gone mad. We cannot let down these people who trust our profession, and it is in this firm resolve that we shall face the future of medicine."

REFERENCES

1 Ryle, J. A., "Social Medicine: Its Meaning and Scope," British Medical Journal, Nov. 20, 1943, p. 633.

2 Health and a Day, 1st ed., 1937, p. 54

3 Final Act of the United Nations Conference on Food and Agriculture, p. 19. 4 Hansard: House of Lords Official Report, July 26, 1938.

5 Ibid., July 29, 1941

6 Virchow, R. L. K., Die Medizinische Reform, 1848, 1, 2.

7 Bourne, Geoffrey, British Medical Journal, 1943, 1, 227.

8 Spencer, Herbert (1891). Essays: Scientific. Political and Speculative, vol. III, p. 477 .

9 Armstrong, E. F., Presidential Address to Royal Society of Arts, Roy. Soc. Arts J., Nov. 26, 1943, p. 9 .

10 Williams, Cicely, British Medical Journal, 1941, 1, 719.

11 Memorandum of the Medical Women's Federation.

12 White Paper, p. 27.

13 Leading Article, British Medical Journal, 1944, 1, 562.

14 Leading Article, Lancet, 1944, 2, 789.

15 Hansard, House of Commons Official Report, No. 49, March 17, 1944.

16 National Service for Health: the Labour Party's Post-war Policy, Transport

House.

17 Beveridge Report, p. 160

18 White Paper, p. 8 .

19 See British Medical Journal, July 8, 1944, p. 54.

20 Dr. Somerville Hastings: "The Doctor of the Future," St. Bart's Hosp. J., June, 1936, p. 172.

21 White Paper, p. 41.

22 Hawthorne, Nathaniel, The Scarlet Letter, Methuen's edition, p. 136

\section{PREGNANCY AND DIABETES}

$$
\text { BY }
$$

MARY A. M. BIGBY, M.D., M.R.C.O.G.

Obstetrician, Central Middlesex County Hospital AND

F. AVERY JONES, M.D., M.R.C.P.

Physician in Charge of Dietetic Department, Central Middlesex County Hospital

This paper is the study of 12 pregnancies in diabet:c women, and in it the wider use of early surgical induction of labour is advocated to diminish the hazards to the infant.

Before insulin was introduced pregnancy in the diabetic was extremely dangerous for mother and child. According to Whitridge Williams (1909) the maternal mortality rate was $27 \%$ during pregnancy, labour, and the puerperium, and a further $23 \%$ in the next two years; the foetal mortality rate was $41 \%$. In the early days of insulin treatment Wilder and Parsons (1928), quoted by Skipper (1933), gave maternal mortality as $12 \%$ and foetal mortality as $47 \%$. The adequate use of insulin has much decreased the maternal mortality rate, but the foetal death rate remains high. In 1942 Lawrence and Oakley. had a maternal mortality of $2 \%$ and a foetal death rate of $37 \%$, but when only their 40 completely supervised cases are considered the latter figure falls to $23 \%$. In the most recent Amer:can series Bill and Posey (1944) give a $27 \%$ foetal death rate.

In this personal series of 12 cases there were no maternal deaths and 2 foetal deaths $(17 \%)$, one being due to a miscarriage and the other to premature death of the foetus in utero.

\section{Maternal Risks}

The diabetic risks to the mother are ketosis and hypoglycaemia, particularly in labour and the early puerperium; but with careful management they can be minimized, and they did not cause difficulties in our cases.

Increased liability to toxaemia is said to be the most important risk, and a high incidence is recorded by American writers. Herrick and Tillman (1938) reported toxaemia in $18 \%$, and White and Hunt (1943) found the incidence as high as $42 \%$ in 119 pregnancies, and thought it accounted for the high foetal mortality. The latter have treated certain cases with large doses of hormones, giving 150,000 to 300,000 units of oestrin and 10 to $20 \mathrm{mg}$. of proluton daily, and reduced the foetal death rate from $40 \%$ in a control series to $8 \%$.

In this country; however, Lawrence and Oakley (1942) found toxaemia in only $10 \%$ of their 54 cases, though a further $15 \%$ had albuminuria and oedema without hypertension, but in none of these cases was the baby stillborn. In this series only one patient developed toxaemia, and she went into labour spontaneously at 32 weeks and produced a live baby weighing $5 \mathrm{lb} .4 \mathrm{oz}$. She then had a post-partum eclamptic fit, but subsequently she and the baby did well. A second case had hypertension from the 22nd week, when she came under observation, the blood pressure being $160 / 100$ to $180 / 120$, but it fell to $120 / 80$ after delivery. She developed slight cedema but no albuminuria.

\section{Foetal Risks}

Diabetics tend to produce fat and post-mature infants. Lawrence and Oakley (1942) think they reach maturity at about 37 weeks, and therefore if left to 40 weeks they are really post-mature. The large size-up to $12 \mathrm{lb}$.-may be due to excessive absorption of sugar or to increased production of growth hormone from the pituitary. The second possibility is favoured, as it does not seem possible to control the size of the baby by controlling the diabetes, for in this series labour was induced before the 37 th week in 9 patients and the babies weighed between $6 \mathrm{lb}$. $6 \mathrm{oz}$. and $9 \mathrm{lb}$., with two exceptions; the baby of the toxaemic patient weighed $5 \mathrm{lb} .4 \mathrm{oz}$. at the $32 \mathrm{nd}$ week and the other $5 \mathrm{lb}$. $6 \mathrm{oz}$. at the 36th week, so that all but the last were over weight by the usual standards. The heaviest infant was born to the mother whose diabetes seemed well controlled by 130 units of insulin daily.

Premature death of the foetus in utero may occur, particularly if pregnancy is allowed to continue to term, and Lawrence and Oakley mention that 7 of the babies of 19 patients who were left to go into labour spontaneously were stillborn. In this series one pregnancy miscarried at the 23rd week, the foetus having been dead 2 to 3 weeks, and one baby died in utero at the 33rd week. Foetal death had occurred at the 32nd week in the latter patient's previous pregnancy, and it was planned to induce labour at the 33rd to 34 th week, when the child would be large enough to have a good chance of survival. The patient was in hospital awaiting induction, with the diabetes satisfactorily controlled, when the child died. Lawrence and Oakley report a similar case in which Caesarean section was delayed for a few days to clear up scabies, and meanwhile the baby died in utero. In neither patient was toxaemia present.

Hydramnios is particularly liable to occur, and was present in 5 of our series. Five, four, and three pints of liquid were withdrawn from 3 patients when the membranes were ruptured, and 2 others had less severe hydramnios. Neonatal death may occur from foetal hypoglycaemia caused by overdevelopment of the pancreas in utero. Sugar was given prophylactically in our series, and this complication was fortunately not seen. Foetal abnormalities are said to be more frequent than usual, but none were found in our cases. One patient, however, since becoming a diabetic had lost her first baby after 3 days from congenital heart disease.

\section{Diabetic Management in Pregnancy}

The patients were given 220 to $300 \mathrm{~g}$. of carbohycirate in a diet supplying 2,000 to 2,500 calories. It is important to maintain a high carbohydrate intake, for it is known that the renal threshold for sugar excretion is lowered during pregnancy, and large amounts of glucose-e.g., 50 to 150 g.may be lost in the urine. It follows that insulin requirements must be judged by blood-sugar readings. Insulin requirements tend to rise in the 2nd trimester and especially in the last 3 months, but may occasionally become less, but this was not observed in our patients.

When the patients first came under observation they were given their usual insulin arrangement. As their insulin requirements increased, for preference they were given soluble insulin in the morning and a mixture of zinc protamine and soluble insulin in the evening. A small or medium dose of zincprotamine-insulin used in this way prevents early morning 


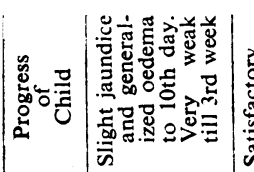

商

\begin{tabular}{|c|c|c|c|c|c|c|}
\hline 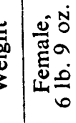 & 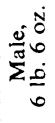 & 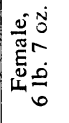 & 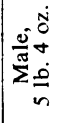 & 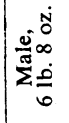 & 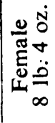 & 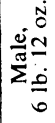 \\
\hline 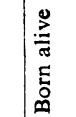 & $\begin{array}{l}= \\
=\end{array}$ & & & $\begin{array}{l}\therefore \\
\therefore\end{array}$ & $\begin{array}{l}= \\
=\end{array}$ & 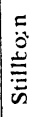 \\
\hline
\end{tabular}

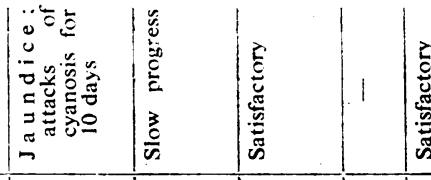

\begin{tabular}{|c|c|c|c|c|c|c|c|c|c|c|c|c|}
\hline 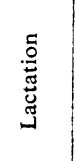 & $\mid \begin{array}{l}0 \\
0 \\
0 \\
0\end{array}$ & r. & 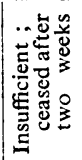 & 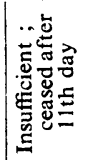 & 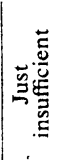 & 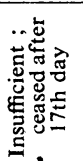 & 1 & $\mid \begin{array}{l}\bar{\sigma} \\
\delta \\
0\end{array}$ & $\begin{array}{l}0 \\
\bar{E} \\
z\end{array}$ & $\mid \begin{array}{l}0 \\
8 \\
0\end{array}$ & 1 & 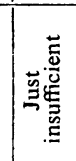 \\
\hline
\end{tabular}

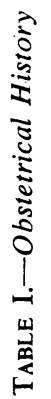

2
0
0

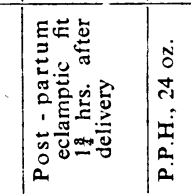

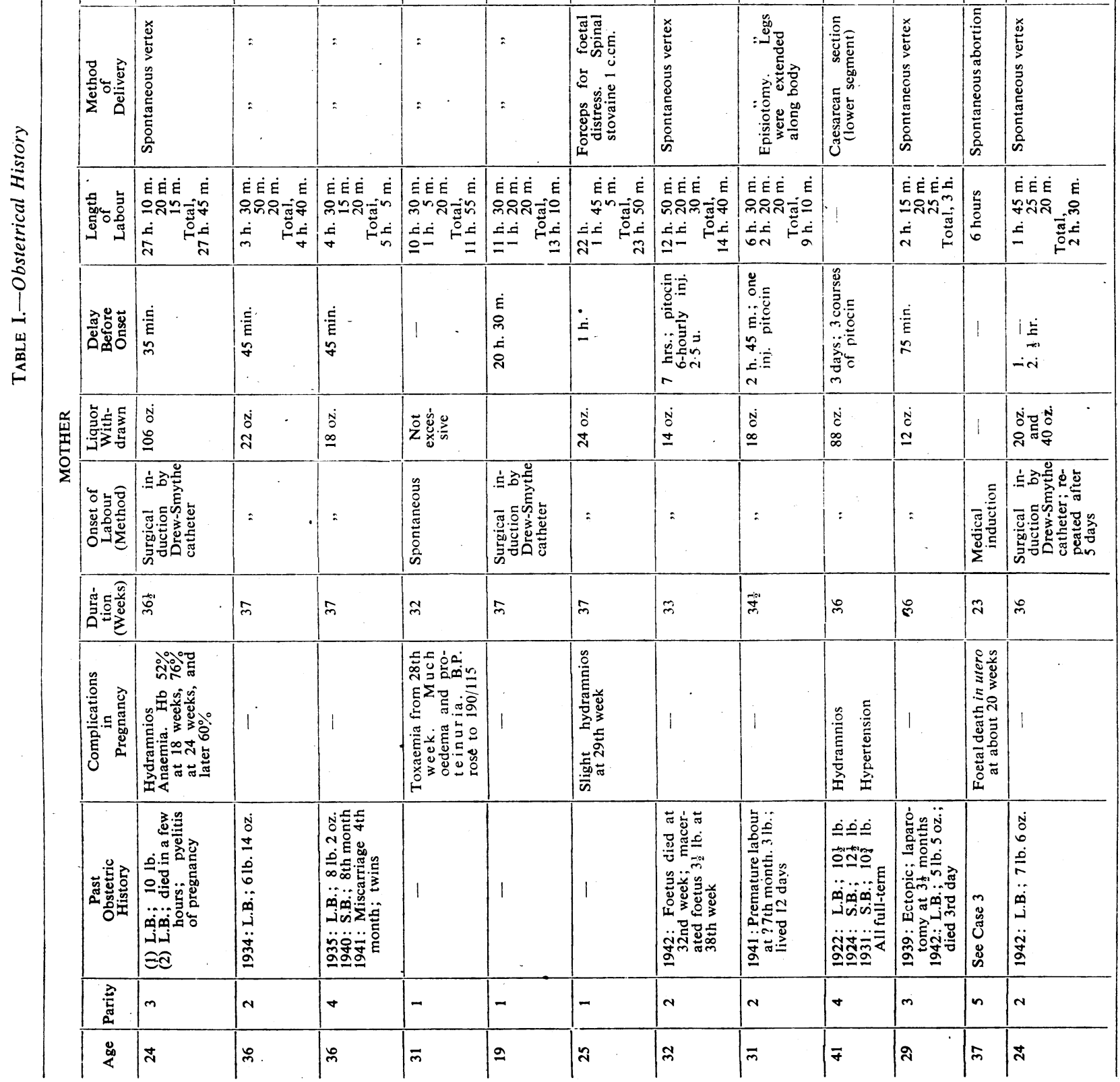


hyperglycaemia without appreciable risk of insulin reactions. This valuable arrangement of insulin was described by Lawrence and Oakley (1944). In very difficult cases it may be advisable to use a third injection, giving soluble insulin before lunch.

During labour the usual diet was given as long as possible, and then glucose (or lactose) 15 to $20 \mathrm{~g}$. 2-hourly and an extra $30 \mathrm{~g}$. at the onset of the second stage. The muscular effect of labour reduces the insulin requirements and there is real danger of hypoglycaemia; the dosage must then be decreased considerably. If there is heavy ketosis, as in two cases, extra glucose should be given : 15 to $30 \mathrm{~g}$. hourly may be needed.

After delivery less insulin is needed as a rule, and a satisfactory working arrangement is to give half the usual amount on the following day and build up the dose if necessary. In two patients the insulin requirements remained unchanged in the puerperium. Both mothers who lost their babies had a temporary increase in insulin requirements; the other patients had their dosage considerably reduced. The two patients who has been used in the present series, which includes two primigravidae. High rupture of the membranes by DrewSmythe catheter was performed, and pitocin 2.5 units hourly may be given for 6 doses if necessary. The induction was performed when it was thought the child would weigh about $6 \frac{1}{2} \mathrm{lb}$., and in most cases this was at 36 to 37 weeks of pregnancy. Labour pains started without undue delay in all but two patients. One was a multipara with hypertension, and after $3 \frac{1}{2}$ days' waiting was finally delivered by lower segment Caesarean section. The other patient had a second surgical induction after 5 days and an additional 2 pints of liquor removed -1 pint having been withdrawn the first time-and then labour began soon afterwards. Delivery was spontaneous in all but one patient who needed a forceps delivery for foetal distress. Otherwise no diabetic or obstetric difficulties were encountered, and early surgical induction certainly seemed a satisfactory alternative to Caesarean section.

Nevertheless operation may be advisable in certain cases if there is any doubt about an easy delivery or if there are any

TABLE II.-Diabetic History

\begin{tabular}{|c|c|c|c|c|c|c|c|c|c|c|}
\hline \multirow{4}{*}{ No. } & \multirow{4}{*}{ Age } & \multirow{4}{*}{ Duration of Diabetes } & \multicolumn{6}{|c|}{ Insulin Requirements } & & \\
\hline & & & \multirow{3}{*}{$\begin{array}{l}\text { Before } \\
\text { Preg- } \\
\text { nancy }\end{array}$} & \multicolumn{3}{|c|}{ During Pregnancy } & \multicolumn{2}{|c|}{ After Pregnancy } & \multirow{2}{*}{ Ketosis } & \multirow{3}{*}{ Comment } \\
\hline & & & & \multicolumn{3}{|c|}{ Trimesters } & \multirow{2}{*}{$\begin{array}{c}\text { On } \\
\text { Leaving } \\
\text { Hospital }\end{array}$} & \multirow{2}{*}{$\begin{array}{l}\text { Some } \\
\text { Time } \\
\text { Later }\end{array}$} & & \\
\hline & & & & Ist & 2nd & 3rd & & & & \\
\hline 1 & 24 & 6 months & $?$ & $27 / 13$ & $26 / 24$ & $16 / 20$ & $26 / 40$ & $20 / 38$ & Traces only & No fall in insulin requirements during and \\
\hline 2 & 36 & $\begin{array}{l}8 \text { years. Diagnosed } \\
\text { when glycosuria } \\
\text { persisted after first } \\
\text { pregnancy } \\
10 \text { years }\end{array}$ & - & 一 & - & $34 / 32$ & $20 / 14$ & $20 / 14$ & , & $\begin{array}{l}\text { Blood-sugar curve at } 3 \mathrm{rd} \text { month }(50 \mathrm{~g} \text {. } \\
\text { glucose }): \text { fasting, } 146 \mathrm{mg} \text {. per } 100 \mathrm{cccm} \text {; } \\
\text { after } \frac{1}{2} \mathrm{hr} \text {, } 195 \mathrm{mg} . ; 1 \mathrm{hr}, 234 \mathrm{mg} \text {; } \\
1 \mathrm{t} \text { hrs., } 230 \mathrm{mg} . ; 2 \text { hrs., } 150 \mathrm{mg} \text {. } \\
\text { Insulin requirements halved on day of } \\
\text { labour }\end{array}$ \\
\hline 4 & 31 & $7 \%$ & - & 一 & 24 & $20 / 36$ & 一 & - & $"$ & An overweight diabetic. Insulin stopped \\
\hline 5 & 19 & 3, & $48 / 32$ & $48 / 32$ & $48 / 32$ & $48 / 32$ & $46 / 30$ & $60 / 30 / \frac{34}{16}$ & , & $\begin{array}{l}\text { Developed Tb. } 16 \text { months later. Insulin } \\
\text { requirements diminished on day of labour } \\
(52 \text { units), but returned immediately to } \\
\text { previous level }\end{array}$ \\
\hline 6 & 25 & 6 & $28 / 20$ & $36 / 20$ & $24 / 34$ & $52 / 26 / 22$ & $\frac{34 / 16}{16}$ & $\frac{34 / 16}{16}$ & $\begin{array}{l}\text { Heavy ketosis } \\
\text { at times and } \\
\text { during labour }\end{array}$ & $\begin{array}{l}\text { Given } 26 / 26 \\
\text { next day }\end{array}$ \\
\hline 7 & 32 & 1 year & $16 / 12$ & $16 / 12$ & $16 / 12$ & $16 / 20$ & $20 / 36$ & $\frac{14}{16}$ & Traces only & $\begin{array}{l}\text { Glycosuria during first pregnancy. Father, } \\
\text { mother, and sister diabetic }\end{array}$ \\
\hline 8 & 31 & $\begin{array}{l}2 \text { years. Diagnosed } \\
7 \text { th month of } 1 \mathrm{st} \\
\text { pregnancy }\end{array}$ & 20 & 20 & 20 & $\frac{24}{20}$ & $\frac{16}{20}$ & $\frac{16}{24}$ & $"$ & Insulin requirements maintained after labour \\
\hline 9 & 41 & $\begin{array}{l}\text { 3rd month of present } \\
\text { pregnancy }\end{array}$ & - & - & - & $16 / 16$ & - & - & , & $\begin{array}{l}\text { Moderate obesity. No diabetic symptoms } \\
\text { but a markedly diabetic blood-sugar } \\
\text { curve. B.P. 160/100-180/110 fell to } \\
120 / 80-140 / 90 \text { after surgical induction, } \\
\text { and stayed down }\end{array}$ \\
\hline 10 & 29 & 4 years & $20: 20$ & $20 ; 20$ & $28: 12 \frac{6}{16}$ & $36 / 20 / \frac{10}{16}$ & $26 / \frac{8}{12}$ & & , & $\begin{array}{l}\text { Insulin requirements reduced by } 32 \text { units } \\
\text { daily after delivery }\end{array}$ \\
\hline 11 & 37 & 11, & 2014 & $20 / 14$ & & & $18 / 14$ & & $", \quad$, & $\begin{array}{l}\text { Insulin requirements temporarily increased } \\
\text { after abortion }(30 / 24)\end{array}$ \\
\hline 12 & 24 & 1 year & $\frac{45}{60} / 50$ & $\frac{45}{60}$ & $\frac{80 / 20}{30}$ & $\frac{80 / 20}{30}$ & $\frac{80 / 20}{30}$ & & $\begin{array}{l}\text { Heavy ketosis } \\
\text { at times and } \\
\text { during labour }\end{array}$ & $\begin{array}{l}\text { Insulin requirements temporarily reduced } \\
\text { after delivery }\end{array}$ \\
\hline
\end{tabular}

Black figures $=$ Zinc-protamine-insulin.

were not having insulin before pregnancy had their injections stopped without any ill effects after delivery.

\section{Obstetric Management}

Premature delivery at 36 to 37 weeks is advisable because of the risk of foetal death in utero near term and of mechanical difficulties due to overlarge babies. The methods available are either Caesarean section or surgical induction of labour.

Caesarean section has been widely advocated for three reasons: because of the large babies, to save the child the risks of labour; because a set operation is a known quantity but labour is uncertain in length and severity; and to enable sterilization to be performed if necessary. Even so, some of the babies may die and the risks of operation to the mother are greater than those of spontaneous delivery. In Lawrence and Oakley's series there weve 27 Caesarean sections, with 2 stillborn babies and 2 neonatal deaths, and one mother died from pulmonary embolus.

Premature delivery by surgical induction of labour was advocated by Brandstrup and Okkels (1938), and its further trial was recommended by Lawrence and Oakley (1942), who had had satisfactory experience in 3 patients. This method additional hazards. A diabetic patient at present under our care who has developed Rhesus antibodies in her serum and having lost two previous babies by premature death in utero will certainly be delivered by Caesarean section.

\section{Management of the Baby}

For the first 24 hours after birth the babies were given glucose- 1 teaspoonful in $1 / 2 \mathrm{oz}$. of water two-hourly-to try to prevent hypoglycaemia. This was given three-hourly for the next day or two, and the infants were breast-fed or given expressed breast milk as soon as possible. Lactation unfortunately tends to be poor in diabetic patients, and the child may need to be given artificial feeds. In this series 3 patients fully breast-fed their infants, and in 4 cases attempts at breastfeeding had to be given up after 2 to $2 \frac{1}{2}$ weeks. There were no neonatal deaths.

\section{Summary}

An account is given of the management of pregnancies in diabetics. In a series of 12 cases 10 babies left hospital with their mothersa better result than in previous published series, and justifying the greater use of surgical induction of labour at 36 to 37 weeks instead of routine Caesarean section. 
Our thanks are due to Dr. Bullimore, Mr. MacVine, Dr. Silberstein, Dr. S. L. Simpson, Mr. Stern, and Miss Titcombe, who kindly referred cases to us, and to the Research Committee of the Middlesex County Medical Society, which facilitated the collection of cases.
We also wish to acknowledge our thanks to Dr. Sakula for his We also wish to acknowledge our
assistance with the neonatal infants.

\section{REFERENCES}

Bill, A. H., and Posey, F. M. (1944). Amer. J. Obstet. Gynec., 48, 405. Brandstrup, E., and Okkels, H. (1938). Acta obstet. gynec. scand., 18, 136 Herrick, W. W., and Tillman, A. J. B. (1938). Surg. Gynec. Obstet., 66, 37. Lawrence, R. D., and Oakley, W. (1942). Quart. J. Med., n.s., 11, 45. Skipper, E. (1934). British Medical Journal, 1, 42

Skipper, E. (1933). Quart. J. Med., n.s., 2, 353 .

Wilter, P., and Hunt, H. (1943). J. clin. Endocrin., 3, 500. 372

Williams, J. W. (1909). Amer. J. med. Sci., 137, 1.

\section{.}

\section{MORTALITY IN CHILDHOOD DURING 1920-38} BY

\section{W. J. MARTIN, B.Sc., Ph.D.Lond.}

(Of the Medical Research Council's Statistical Staff) London School of Hygiene and Tropical Medicine

During the inter-war period considerable success had attended the efforts to reduce mortality, particularly in the first years of life. It seems of interest to review briefly the trend of childhood mortality during the 20 years of peace, since with the prospects of a continued decline in the size of the child population, and the wastage of young adult life due to war, the health and welfare of the child population will become of still greater importance to the nation in the future. The death rates in England and Wales during the first 15 years of life, for males and females for four periods covering 1920-38, are given in Table I. Mortality declined at each age throughout that

TABLE I.-Death Rates per 1,000 from All Causes: England and

\begin{tabular}{|c|c|c|c|c|c|c|c|c|}
\hline \multirow{2}{*}{ Ages } & \multicolumn{4}{|c|}{ Males } & \multicolumn{4}{|c|}{ Females } \\
\hline & $1920-4$ & $1925-9$ & $1930-4$ & $1935-8$ & $1920-4$ & $1925-9$ & $1930-4$ & $1935-8$ \\
\hline $\begin{array}{c}0- \\
1- \\
2- \\
3- \\
4- \\
5- \\
6- \\
7- \\
8- \\
9- \\
10- \\
11- \\
12- \\
13- \\
14-\end{array}$ & $\begin{array}{r}86.9 \\
23.0 \\
9.7 \\
6.0 \\
4.5 \\
4.0 \\
3.2 \\
2.6 \\
2.1 \\
1.9 \\
1.8 \\
1.7 \\
1.7 \\
1.7 \\
1.9\end{array}$ & $\begin{array}{r}79.8 \\
20.9 \\
8.7 \\
5.3 \\
4.0 \\
3.6 \\
2.7 \\
2.3 \\
2.1 \\
1.8 \\
1.6 \\
1.6 \\
1.5 \\
1.6 \\
1.8\end{array}$ & $\begin{array}{r}70.8 \\
14.8 \\
6.5 \\
4.4 \\
3.6 \\
3.5 \\
2.7 \\
2.2 \\
1.8 \\
1.6 \\
1.5 \\
1.4 \\
1.4 \\
1.5 \\
1.7\end{array}$ & $\begin{array}{r}63.5 \\
10.2 \\
4.7 \\
3.5 \\
3.0 \\
3.0 \\
2.4 \\
1.9 \\
1.5 \\
1.4 \\
1.3 \\
1.2 \\
1.2 \\
1.3 \\
1.5\end{array}$ & $\begin{array}{r}66.9 \\
20.8 \\
9.1 \\
5.7 \\
4.3 \\
4 \cdot 0 \\
3.0 \\
2.4 \\
2.0 \\
1.8 \\
1.7 \\
1.6 \\
1.7 \\
1.9 \\
2.1\end{array}$ & $\begin{array}{c}61.6 \\
18.8 \\
8.1 \\
5.0 \\
3.7 \\
3.3 \\
2.6 \\
2.1 \\
1.8 \\
1.6 \\
1.4 \\
1.4 \\
1.5 \\
1.6 \\
1.8\end{array}$ & $\begin{array}{r}54.3 \\
13.0 \\
5.9 \\
4.1 \\
3.4 \\
3.1 \\
2.5 \\
1.9 \\
1.7 \\
1.5 \\
1.3 \\
1.3 \\
1.4 \\
1.5 \\
1.6\end{array}$ & $\begin{array}{r}48.9 \\
8.9 \\
4.3 \\
3.1 \\
2.7 \\
2.6 \\
2.2 \\
1.7 \\
1.5 \\
1.3 \\
1.1 \\
1.1 \\
1.1 \\
1.2 \\
1.3\end{array}$ \\
\hline
\end{tabular}

period; the greatest relative improvement occurred at ages 1-2 and $2-3$, in which the rates had been more than halved. At ages 3-4 the death-rate had decreased by over one-third, and there was an improvement of one-quarter in the infant mortality rate. A slight difference occurred in the relative trends of the mortality of boys and girls during this period. The minimum death rate for girls during 1920-4 was at age 11, but during 1935-8 mortality did not increase until age 13. There was no corresponding change in the trend of the boys' mortality, and as a consequence the death rate for girls aged 13 and 14 in 1935-8 was below that of the boys, while in 1920-4 the boys had a slightly lower rate at these ages than the girls. The mortality at age 5 showed an interesting trend: in the first period the death rate at this age declined by a smaller amount than in the preceding or succeeding age. This kink in the curve has become more pronounced, and in the last period the mortality at age 5 showed no improvement on that of age 4 . This break at age 5 in the downward curve of mortality may be due to the greatly increased risk of infection that confronts children on entering school life, or it may be of significance as indicating a hiatus in child welfare.

\section{Infant Mortality}

Before considering childhood mortality by cause of death it is convenient to examine the mortality of infants, since the bulk of these deaths are attributed to causes peculiar to the first year of life. The great improvement in infant mortality has arisen mainly from the decrease in deaths from infectious and general diseases. The mortality from diseases peculiar to infancy has undergone only a slight improvement. The rates for various causes are shown in Table II.

TABLE II.-Infant Mortality in England and Wales

\begin{tabular}{|c|c|c|c|c|c|}
\hline & & $\begin{array}{c}\text { All } \\
\text { Causes }\end{array}$ & $\begin{array}{l}\text { Congenital Malformation; } \\
\text { Congenital Debility; } \\
\text { Premature Birth; } \\
\text { Injury at Birth }\end{array}$ & Violence & $\begin{array}{c}\text { Infectious } \\
\text { and } \\
\text { General } \\
\text { Diseases }\end{array}$ \\
\hline $\begin{array}{l}1920-4 \\
1925-9 \\
1930-4 \\
1935-8\end{array}$ & $\begin{array}{l}\cdots \\
\cdots \\
\cdots\end{array}$ & $\begin{array}{l}77 \cdot 1 \\
70 \cdot 9 \\
62 \cdot 7 \\
56 \cdot 4\end{array}$ & $\begin{array}{l}33 \cdot 8 \\
32 \cdot 2 \\
32 \cdot 2 \\
30 \cdot 6\end{array}$ & $\begin{array}{l}0 \cdot 95 \\
0.99 \\
1 \cdot 16 \\
1 \cdot 12\end{array}$ & $\begin{array}{l}42 \cdot 4 \\
37 \cdot 7 \\
29 \cdot 3 \\
24 \cdot 7\end{array}$ \\
\hline
\end{tabular}

The fall in the rates of the second column was due to the decline of mortality from congenital debility from 8.09 in 1920 to 1.76 in 1938 . A matter for concern is the steady rise in deaths due to injury at birth-from 1.22 in 1920 to 2.59 in 1938. A similar trend has been shown by the United States of America, where the mortality from injury at birth rose from 3.9 in 1920 to a peak of 5.3 in 1930 and then declined slightly to 4.8 in 1939 . It seems rather ironical that, despite the efforts to reduce mortality, the death rates from violence should increase. In terms of rates the difference of $\mathbf{0 . 1 7}$ between the first and last periods is small, but if there had been no increase 410 fewer babies would have been killed during 1935-8.

Although infant mortality has steadily improved since the beginning of the present century, when the rate was 160 per 1,000 births, a considerable improvement can still be effected. This is shown by comparison with the mortality rate in other countries :

\begin{tabular}{|c|c|c|c|c|c|}
\hline Country & & $\begin{array}{c}\text { Infant Mortality, } \\
1935-9\end{array}$ & Country & & $\begin{array}{c}\text { Infant Mortality, } \\
1935-9\end{array}$ \\
\hline New Zealand & . & 32 & Denmark & & 64 \\
\hline olland .. & . & 38 & Germany & $\cdots$ & 64 \\
\hline Australia .. & . & 39 & France & $\ldots$ & 66 \\
\hline Norway ... & . & 40 & Canada & . & 67 \\
\hline Sweden $\ldots$ & .. & 43 & Belgium & . & 75 \\
\hline U.S.A. $\quad \cdots$ & i. & 49 & Scotland & $\cdots$ & 76 \\
\hline England and & iles & 55 & Italy ... & $\because$. & 103 \\
\hline
\end{tabular}

The infant mortality rate of New Zealand is only a little more than half that of England and Wales. In the United States infant mortality has declined faster than in this country. The rates for 1920 and 1939 were 86 and 44 in the U.S.A. and 80 and 55 in England and Wales. A similar difference in trend occurred between London and New York. The rates for London fell from 76 in 1920 to 47 in 1939, while those for New York were 85 and 37. In 1939 the rates for each of the five boroughs of New York were below the rate for London. The values were: Manhattan, 45.7 ; Queens, 36.5 ; Brooklyn, 34.9 ; the Bronx, 32.1 ; and Richmond, 31.0. It is not possible to assess the relative difference of the maternal and child welfare services of the two countries. In the U.S.A., at present, facilities for maternal care for those who cannot pay are provided for only to a very limited extent out of public funds.' Probably a part of the greater improvement in that country is due to the success attending the efforts made by ante- and post-natal clinics to increase maternal efficiency. Efforts have also been made to raise the standard of medical care by postgraduate education in paediatrics and obstetrics for practising physicians; and in New York and some other cities minimal standards for maternity services are enforced as public health regulations. With regard to England and Wales, it appears to be doubtful whether full use has been made of existing child welfare clinics. Statistics in a suitable form are not available, but the reports of the local medical officers of health suggest that, although in some areas over $90 \%$ of the children born attended a clinic, the total attendance per birth per year was low-of the order of 10. A fair inference is that the majority of mothers failed to take their baby more than once or twice to the clinic. The relative importance of the factors influencing infant mortality has not been established, since most conditions which have a close correlation with infant mortality have also a high degree of association with each other. Within the country there is a considerable negative correlation between infant mortality and economic and environmental 